\title{
Pathways to the Future: The New Diplomacy for Sustainable Development
}

\section{Bo Kjellén}

\section{Introduction}

As a negotiator and practitioner of multilateral diplomacy in many different contexts over 40 years, beginning with the first UN Conference on Trade and Development (UNCTAD) in Geneva in 1964, I have had many reasons to reflect upon the role of international cooperation in a rapidly changing world. Since 1990, I have been actively involved in many of the negotiations related to sustainable development, both in the normative context of the Rio Conference in 1992 and its follow-up at the 2002 World Summit on Sustainable Development (WSSD) held in Johannesburg. I have also been involved in the processes of negotiating legally binding agreements, such as the UN Framework on Convention on Climate Change (UNFCCC) and on the Convention on Combatting Desertification (CCD).

These experiences have convinced me that a new branch of diplomacy has emerged since the 1980s, dealing with a new set of global problems. This article describes key features of the emerging pattern of diplomacy which I believe will shape profoundly the way in which the international community, comprising states but also other actors, interact to address increasingly interrelated global problems. The first part of the article sketches out the economic, demographic and political changes that set the global context for future international cooperation. The concept of sustainable development which emerged at Rio and which now provides the overarching framework for international cooperation is then discussed with particular emphasis placed on the social dimension of globalisation - an aspect which has tended to be overlooked in the quest for integration of the environmental and developmental components of sustainable development. I then outline key features of the new diplomacy and how it differs from other forms of international cooperation based on traditional forms of power relations. The final section examines North/South issues which emerged in the 1964 UNCTAD negotiations at the beginning of my career and which continue to dominate many policy discussions today ending regrettably in too many cases of stalemate. The conclusions suggest new research is needed to find ways to better understand the underlying tensions and how to address these in a radically changed world. To be successful, the new diplomacy for sustainable development will also require reforming the role of international organisations and most importantly, advancing the critical task of increasing public understanding of the new global threats and resulting responsibilities.

\section{The global context}

Like other international issues, climate negotiations take place against the background of major changes that are increasing the world's population and the increasing wealth of a part of mankind: since 1950, the global economy has increased by more than a factor of 15 , but economic inequality is also increasing. Today the richest countries have 15 per cent of the global population, but generate 50 per cent of world GDP. Transport accounts for 25 per cent of world energy use and the number of motor vehicles has increased from 40 million in the late 1940 s to 672.6 million in 1996. From 1950 to 2000 , the percentage of the world's population living in urban areas increased from 30 per cent to 47 per cent and it is projected to increase to 56 per cent by 2020 .

These developments have been accompanied by an unprecedented pressure on Earth's resources and on the planet's capability to assimilate wastes 
from human activities. Even though petroleum was only discovered and used over the last 150 years, we have already exhausted 40 per cent of known oil reserves and in the process of burning fossil fuels the concentration of carbon dioxide in the atmosphere has increased from $280 \mathrm{ppm}$ in preindustrial times to $370 \mathrm{ppm}$ today; and the increase is accelerating. Nearly 50 per cent of the land surface has been transformed by direct human action and more than half of all accessible freshwater resources have been appropriated for human purposes. Extinction rates are increasing sharply in marine and terrestrial ecosystems around the world; experts speak of the sixth great extinction event in the Earth's history, but this time caused by human activities and pressures. See also O'Riordan et al. (2002).

These facts, most recently highlighted in the 2004 International Geosphere-Biosphere Programme (IGBP) publication Global Change and the Earth System, are indeed sobering (Steffen et al. 2004). They have led to suggestions that we are now living in a new geological era, the Anthropocene (Crutzen and Stoermer 2001).

The anthropogenic impact on the Earth system is a truly global phenomenon. But it has to be seen in the context of what is now generally called globalisation. The concept has been given many interpretations and there is no consensus on the evaluation of its many facets, be they economic, social, cultural or political. However, with particular reference to the problems of development, many observers have concluded that globalisation has negative effects for the South, leading to more inequality and less opportunity for developing countries. Furthermore, it is argued that increased trade, transports and movement of labour tends to intensify the pressures on the world environment. All these elements have been driving forces behind the anti-globalisation movement and the alternative world summits, the latest one being held in India.

\section{The social dimension of globalisation}

These widely diverging views led to the establishment by the International Labour Organization of a World Commission on the Social Dimension of Globalization, which recently published its report. The Commission was cochaired by President Tarja Halonen of Finland and President William Mkapa of Tanzania. ${ }^{1}$

The report is a collective document and it can be criticised for papering over divergences between the members of the Commission, through too much compromise language and recommendations that are too general. Nevertheless, it is an authoritative effort of analysing the implications of a phenomenon, which cannot be reversed and which originated in the post-World War II reaction to the 1930s, when economic and political nationalism led to disastrous consequences.

Against the background of a generally positive attitude to globalisation, the Commission concluded that the current process of globalisation is generating unbalanced outcomes, both between and within countries. Wealth is being created, but too many countries and people are not sharing in its benefits'.

The report is particularly addressing the social consequences of globalisation, with specific reference to the economic forces behind the phenomenon. The environmental aspects of sustainability are not considered in detail, but the report gives valuable insights into the challenges facing multilateral diplomacy also in this regard.

First, there is no doubt that environment is part of the concerns surrounding globalisation. The report states that 'a truly global conscience is beginning to emerge, sensitive to the inequities of poverty, gender discrimination, child labour and environmental degradation, wherever these may occur'. Furthermore, the additional economic growth created by globalisation of markets has to be made compatible with the requirements of the functioning of the earth system in terms of climate, biological diversity etc.

Second, the report underlines elements of uncertainty engendered by rapid change and globalisation and it quotes a participant from Costa Rica, who says: 'There is a growing feeling that we live in a world highly vulnerable to changes we cannot control'. Certainly the concept of global environmental change gives a particular emphasis to this feeling of vulnerability and fragility. See also Raskin et al. (2002).

Third, as one of the main recipes for moving globalisation in a more constructive direction, the report argues strongly in favour of a reinforcement of the multilateral system and and an improvement in the quality of global governance. One important proposal in the report is for "Policy Coherence Initiatives", which would engage key international organisations in developing a common integrated 
approach to key global concerns. Institutional change in the multilateral system is in fact a central element of an efficient international diplomacy for sustainable development.

\section{The concept of sustainable development}

It is in this global perspective that the concept of sustainable development takes on a special importance. The main reason for this is obviously that ours is the first generation which can fundamentally influence the whole global system. And it is against the background of the definition of sustainable development in the 1987 Brundtland Report (World Commission on Environment and Development, 1987) that so many of the multilateral negotiations have been held over the last decade. In particular, I think we have to realise the importance of linking the development imperative to the need to approach ecological sustainability in a way which is acceptable from the equity point of view.

The Brundtland Report's original definition is in fact very carefully drafted:

Sustainable Development seeks to meet the needs and aspirations of the present without compromising the ability to meet those of the future. Far from requiring the cessation of economic growth, it recognises that the problems of poverty and underdevelopment cannot solved, unless we have a new era of growth in which developing countries play a large role and reap large benefits. (World Commission on Environment and Development 1987: 40)

The increasing recognition of the three main elements of sustainability has contributed to the usefulness of the concept. The political discourse today encompasses economic, social and ecological sustainability. In practical policy terms, it means that a new parameter has been added to the governments' traditional responsibility for maintaining economic and social sustainability. But the new element is environment and an important challenge to policy formation today is to give these new concerns their proper place in relation to other, more established, policy objectives. See also World Bank (2003).

The simple triangular relationship between the components of sustainability is of course convenient in terms of the presentation of governments' policies and ideas. But the real world is of course much more complicated, with a practically unlimited number of factors influencing policy making at all levels. It is also undeniable that other factors influence the perception of sustainability, such as demography, lifestyles, or technological change. Furthermore, beyond the daily concerns facing governments and individuals there are profound movements that shape the realities of an era and permeate almost all expressions of ideas and almost all activities in societies, including governments' policies.

It is against this background that we have to consider the emergence of what I wish to call the new diplomacy for sustainable development. ${ }^{2}$

\section{Key features of the new diplomacy}

Some may argue that it is presumptuous to talk about a "new diplomacy". What about trade policy or international economic diplomacy in general, which have co-existed with traditional security and foreign policy concerns for more than a century? I believe that the general background already provided indicates that we are in the presence of new mechanisms and structures of international relations.

Traditional diplomacy is ultimately based on power relations. It may be argued that the present US approach to international relations is a clear example of this line of action: lack of confidence in the UN and the multilateral method with its efforts to reach laborious compromises; a clear distinction between friends and adversaries; "demonisation" of certain parties; reliance on military strength.

But the global sustainability issue is of a different nature. The Rio process has laid the basis for a framework of a new kind of negotiation which is more integrative and where the bottom line is the concern for long-term human survival. This is a very different reality from the quest for military supremacy or economic superiority, based on the impoverishment of others (intra-generational equity) and unsustainable depletion of the natural resource base (inter-generational equity). As all negotiators in the Rio process know, this does not mean that solutions are easy to find: powerful political, economic and social interests are challenged by the need to ensure gains are equitably spread as well as sustainable - among and between present and future generations. Progress towards 
this end is painstakingly slow. But the fundamental objective of international negotiations is different. A few specific points will illustrate these differences.

\subsection{It is necessary to consider the underlying vision}

Traditionally, diplomacy is aimed at promoting the interests of a sovereign or of a nation. These could of course be linked to other concerns, such as the stability of a region or a long-term aim of international stability through the establishment of the United Nations after World War II, or through the creation of the European Economic Community in 1957.

But in the Anthropocean era, the vision has to become more global and systemic, more long term, in the case of climate change stretching 50,100 or 200 years into the future. This requires a new mindset and ultimately a changing societal paradigm to underpin international negotiations. It is no longer good enough just to defend national or regional interests: the global concern for the future of the human species has to be integrated into the thinking of negotiators. We can negotiate about climate change, but we cannot negotiate with climate change.

\subsection{This new diplomatic landscape needs to be illuminated by science and research}

The natural sciences have been driving many of the negotiating processes, such as the successful efforts to limit the threat to the ozone layer through the ban on ozone-depleting substances. The essential role of the natural sciences in the climate negotiations is well documented. The "Summary for policy makers" of each successive Intergovernmental Panel on Climate Change (IPCC) Assessment Report has had a significant impact on Governments' perceptions of the problems with a corresponding impact on the course of negotiations. In the negotiations on the Convention to Combat Desertification, a Panel of Experts - composed of eminent scientists - was established to guide the work of the Secretariat. This group had a very considerable impact, particularly in the early stages of the negotiation (Kjellén 2003).

In all these examples, the natural sciences have been the driving force. This is understandable, but it has become increasingly clear that the social sciences need to be involved in different ways. Since so much of the analysis of possible action hinges on the question of costs, it is quite obvious that economics plays an essential role; but also political science, sociology and social psychology are essential and this is mainly for two reasons: the instructions given by national governments to negotiators are dependent on a broad range of factors, which needs to be analysed; and the results of negotiations need to be supported by a wide range of actors if implementation at the national level is to succeed. Since international agreements on these complex issues will have a deep impact on societies, social science research has a key role in helping to analyse the kind of change that will support sustainable development.

\subsection{Civil society, mainly NGOs and representatives of local communities, have been directly involved at a scale unknown in traditional diplomacy}

The broad character of the problems requires consultations that go far beyond the traditional channels; new groups need to be brought in, including, e.g. grass-root non-governmental organisations (NGOs), which were present all through the desertification negotiations. This has been recognised in formal decisions, first of all by the Preparatory Committee for the Rio Conference, which at its first session ruled that NGOs were not formal negotiating parties, but that they had the right to extensive presence at meetings.

Furthermore, the active lobbying by NGOs of different kinds and the organisation of side events have given the negotiations on sustainable development a distinctive character, with seminars, workshops and exhibitions creating a dynamic environment and a sense of participation, enhancing the value of the formal negotiations. As a negotiator, I have always been struck by the impact of this active presence of non-governmental actors around the formal processes. ${ }^{3}$

\subsection{New countries have entered centre stage in the negotiations and other traditional players have assumed new importance}

It goes without saying that the great powers representing the South, such as China, India and Brazil (together representing more than 40 per cent of the world's population) are central to the negotiations on global sustainability. But it is also striking that groupings of small countries, often 
based on their very vulnerability to environmental hazards, have become active participants in negotiations in ways that was not foreseen ten years ago. The Alliance of Small Island States (AOSIS) and the drought-stricken African countries cooperative response comes to mind. This has triggered others to become better organised. In relation to climate change, the Organisation of Petroleum Exporting Countries (OPEC) and in particular Saudi Arabia, have been a particularly forceful group, defending the interests of oil producers in a vocal way and rallying considerable support in the Group of 77 (in fact, five out of the seven most recent G-77 Chairs have been members of OPEC - Indonesia (1998), Nigeria (2000), Iran (2001), Venezuela (2002) and Qatar (2004) - see Yamin and Depledge forthcoming).

The Rio process and the subsequent negotiations relating to the Rio Conventions (climate, desertification, biodiversity), have coincided with the consolidation and enlargement of the European Union, which from May 2004 will comprise 25 countries. The EU has had a very considerable impact as a driving force in most of these negotiations and will continue to find its voice as a global leader on many issues.

\section{The North/South divide}

In considering the specifics of the new diplomacy, it might be argued that the North/South issues need to be given particular attention. Efforts to safeguard intra-generational equity are a necessary prerequisite for achieving effective international action to defend the interests of future generations (Mwandosya 2000). The Millennium Declaration of the United Nations and the Plan of Implementation adopted by the World Summit on Sustainable Development in Johannesburg 2002 have justifiably focused on combating poverty and the need to support development efforts. But it has to be admitted that the performance of the developed countries since the 1990s has not been very impressive, in terms of effectively tackling the growing international inequities.

It may well be that a more constructive relationship between North and South could be decisive for the success of the new diplomacy and I would submit that there is a need for a more thorough analysis of these issues. Within the framework of this article, I wish to highlight a few aspects of particular relevance to the problematic, against the background of the experience of the last 30 years.

Since the Stockholm Conference on the Human Environment in 1972, the problems of development and the problems of environment have been linked in an antagonistic relationship. In Stockholm, Prime Minister Indira Gandhi of India took the lead, underlining that the central problem of the developing countries was not environmental deterioration, but unacceptable poverty and lack of resources. The final agreements in Stockholm managed to bridge the gap in words, but the reality has haunted environmental negotiations ever since.

One of the results of the Stockholm Conference was the decision to establish the Headquarters of the new UN Environment Programme in Nairobi, the first UN Headquarters outside the developed world. The decision had a symbolic value; a few years later it was further reinforced by the appointment of Dr Mostafa Tolba of Egypt to succeed the Canadian Maurice Strong as Executive Director of the Programme.

In the preparations for the Rio Conference, representatives of developing countries took a cautious line with regard to the concept of sustainable development. This was also reflected in the official title of the Conference: The UN Conference on Environment and Development. In fact it took quite some time before the notion of sustainable development was finally accepted (early examples include its reference as an overall objective in the treaties establishing the European Union and in the preamble of the 1994 World Trade Organisation (WTO) agreement). But finally the expression was also reaffirmed at the World Summit in Johannesburg in 2002.

The fundamental reason for the initial cautious G-77 approach has been the concern that action to safeguard the environment would slow down the combat of poverty and the efforts of achieving economic growth. There was also a strong philosophical justification for this attitude: the industrialised countries share the main responsibility for global environmental degradation and they therefore have the responsibility to take action for redressing the problems. In the various Rio texts, including the Climate Convention, the formula used has been 'common but differentiated responsibility'. ${ }^{4}$

We also have to recognise that one of the main reasons why the Rio process has seen continued 
North/South skirmishes has been the inability of the developed countries to live up to some of the central commitments included in Agenda 21. It is of course true to say that Agenda 21 is not a legally binding document, but some of the language related to transfer of financial resources in Agenda $21 \mathrm{Ch}$. 33, in particular linked to the 0.7 per cent target of Official Development Assistance (ODA) was quite precise, whereas in fact global ODA transfers related to GDP have actually been reduced after Rio. Also, the increasing global inequalities and other tensions in the world have made agreements between North and South more difficult.

For anyone who has been involved in North/ South negotiations ever since the first UN Conference on Trade and Development in 1964 - which actually was the beginning of the Group of 77 (the number of developing nations at the time), it is striking how many themes that reappear along the fault line between North and South in multilateral negotiations.

There is the constant demand from the South for new funding, justified but often linked to the creation of new mechanisms. There is a reluctance in the North to consider seriously well-motivated proposals from the South. There is the tendency to amplify conflicts in a rather sterile negotiating environment where group positions carry too much weight, because the groups - not least the G-77 are very heavy mechanisms.

In the climate negotiations today, one of the fundamental problems is the uncompromising position taken by the oil-producing countries, in particular Saudi Arabia. At the present time, it is difficult to see how these different perceptions of energy policy can best be accommodated. It might be interesting, however, to study carefully what was said and done during one of the most forgotten episodes of North/South economic relations over the least half century, the Conference on International Economic Cooperation (CIEC), which attracted tremendous interest in the period after the first oil shock with Ministerial Conferences in 1975 and 1977 and very intense technical work between these two meetings. ${ }^{5}$

On the positive side, there is the capacity of different personalities or delegations to break out of this mould and make agreements that carry the process forward. This has happened at crucial moments in the Rio process and in the Convention negotiations, often because of personal contributions by Southern diplomats, such as Tommy Koh of Singapore chairing the Rio Preparatory Committee or Raul Estrada of Argentina chairing the Kyoto Conference of Parties on Climate and it will happen again.

But for any observer of the evolution of the new diplomacy for sustainable development it should be obvious that more effort has to go into the analysis of the fundamental problems related to poverty and inequality. The Johannesburg Summit made many references to poverty, but we are still far from a sufficient understanding of what is really required to tackle the issues involved in a precise way, enabling the international community to understand better the relationship between inter-generational equity and intra-generational equity. Among the criteria mentioned as characteristics of the new diplomacy, I mentioned above the appearance of new actors, such as the small island states or the least developed countries. These new actors need to build up their capacity to really participate in international negotiations in an efficient way. They need to have the tools to build independent research and observation capacity of environmental phenomena.

But above all, we need to better analyse the reasons for what Roger D. Hansen already in 1980 called the 'North/South stalemate' (Hansen 1980). At the time the global environmental threats had not yet risen above the horizon, the expression "sustainable development" had not yet become known. But the lack of understanding of the mechanisms that create these tensions remains and it would seem to me to be an urgent task for research to assist the new diplomacy in understanding these tensions and finding new ways around them in the radically changed world of the early twenty-first century.

\section{Conclusion: a new diplomacy and a new societal paradigm}

Any multilateral negotiator knows that a prerequisite for successful negotiation is the instruction decided in the home capital, its flexibility, its capacity to define conflicting domestic interests in such a way that constructive negotiating positions can be achieved. The global perspectives outlined in this article and the very dimensions of the problems that have to be tackled at the international level require an extraordinary intellectual and political effort by governments. International organisations, 
in particular the UN, have to carry out important reforms to meet the new challenges.

But there is also a need for societal changes, which cannot be imposed from above, but have to follow on from an increasing public understanding of the pressures that the Anthropocene era imposes on the global system. There is no panacea, no quick fix, only a growing public understanding of a new kind of threat. During the Cold War, societies and public thinking were somehow geared to the dangers inherent in the Cold War and the nuclear

\section{Notes}

1. Press release issued by the ILO, 24 February 2004 (ILO/04/07).

2. The notion of a "new diplomacy" was used by the author in a speech given in New York on 11 May 1999. (Pace Environmental Law Review, Vol 17 No 1/Winter 1999, New York/Westchester: Pace University)

3. A Swedish scholar, Elisabeth Corell, has suggested that in the case of the desertification negotiations, NGOs had more impact than the scientific Panel of Experts (Corell 1999).

\section{References}

Corell, E., 1999, The Negotiable Desert, Motala: Linköping Studies in Art and Science

Crutzen, P.J. and Stoermer, E., 2001, 'The Anthropocene', International Geosphere Biosphere Programme, Global Change Newsletter 41: 12-13

Dasgupta, C., 1994, 'The Climate Change Negotiations', in I. Mintzer and J.A. Leonard (eds), Negotiating Climate Change, The Inside Story of the Rio Convention, Cambridge: Cambridge University Press and Stockholm Environment Institute

Hansen, R.D., 1980, Beyond the North/south Stalemate, Washington, D.C.: Council of Foreign Relations

Kjellén, B., 2003, 'The saga of the convention to combat desertification', RECIEL, Review of European Community and International Environmental Law, Vol 12 No 2

Kjellén, B., 1993, 'Lessons to be Drawn for the Future', in International Environmental Negotiations, Stockholm/Uddevalla: Swedish Council for Planning and Coordination of Research (FRN)

Mwandosya, M.J., 2000, Survival Emissions, A Perspective from the South on Global Climate Change Negotiations, University of Dar-es-Salaam: DUP Limited balance. Today, the threat of terrorism is becoming apparent and action is taken at many levels to counter it. But the less tangible threat of global change is difficult to visualise, as it is difficult to think in the long term. Somehow, our societies will have to make the effort; and not all the risks are on the down side. There may be surprising successes achieved through new technology and important breakthroughs in terms of thinking and culture, as our global responsibility becomes better understood.

4. An interesting presentation of the G-77 argument is to be found in an article by the Indian Chief Negotiator, Chandrasekhar Dasgupta, in the SEI book Negotiating Climate Change (1994) Cambridge University Press.

5. The reports are available in a 1977 document entitled 'Conference on International Economic Cooperation'.

O'Riordan, T. and Stoll-Kleemann, S. (eds), 2002, Biodiversity, Sustainability and Human Communities, Cambridge: Cambridge University Press

Raskin, P., Banuri, T., Gallopin, G., Gutman, P., Hammond, A., Kates, R. and Swart, R., 2002, Great Transition, The Promise and Lure of the Times Ahead, Boston: Stockholm Environment Institute Steffen, W., Sanderson, A., Jäger, J., Tyson, P.D., Moore III, B., Matson, P.A., Richardson, K., Oldfield, F., Schellnhuber, H.-J., Turner II, B.L. and Wasson, R.J., 2004, Global Change and the Earth System. A Planet Under Pressure, Berlin/Heidelberg: Springer Verlag

World Bank, 2003, World Development Report 2003: Sustainable Development in a Dynamic World, Oxford: World Bank and Oxford University Press

World Commission on Environment and Development, 1987, Our Common Future, Oxford: Oxford University Press

Yamin, F. and Depledge, J., forthcoming 2004, The International Climate Change Regime: A Guide to Rules, Institutions and Procedures, Cambridge: Cambridge University Press 